\title{
The Quality of Regional Government and Firm Performance
}

\author{
Fernanda Ricotta ${ }^{1}$ \\ ${ }^{1}$ Department of Economics, Statistics and Finance "Giovanni Anania", University of Calabria, Arcavacata di \\ Rende, Italy \\ Correspondence: F. Ricotta, Department of Economics, Statistics and Finance "Giovanni Anania", University of \\ Calabria, Arcavacata di Rende, Ponte Pietro Bucci - Cubo 0/C, 87036 Arcavacata di Rende (CS) - Italy. Tel: \\ 39-098-449-2407.E-mail: fernanda.ricotta@unical.it
}

Received: November 15, 2018

Accepted: December 21, 2018 Online Published: December 30, 2018

doi:10.5539/ijef.v11n2p27

URL: https://doi.org/10.5539/ijef.v11n2p27

\begin{abstract}
This paper examines the effect of the quality of regional government (QoG) on firm Total Factor Productivity (TFP) in a multi-country context. The analysis is based on comparable cross-country data of manufacturing firms operating in seven European countries. To disentangle internal from external productivity drivers, the multilevel approach is employed. Results show that firms' characteristics are important but external factors also play a role. As regards the specific scope of this paper, the results provide evidence that institutional differences within countries do matter for firm performance. The attempts made to address endogeneity problems confirm the positive and significant impact of the quality of regional institutions on firm performance.
\end{abstract}

Keywords: institutions, firm performance, European regions, multilevel model

\section{Introduction}

The performance of a firm is influenced by decisions made by the firm itself as well as external factors. Firm competencies are important but also competencies that pertain to territories where the firm is based (Mariani, 2004). External factors encompass different aspects of the environmental context, such as physical infrastructures, innovative capacity and efficiency of the public administration.

The attention in this paper is on the effect of the quality of regional government (QoG) on the Total Factor Productivity (TFP) of firms in a multi-country context.

Scholars have demonstrated that the institutional environment affects macro variables such as growth, income level, productivity, innovation, investment and trade at the country (Acemoglu et al., 2001; Hall \& Jones, 1999; Barbarosa \& Faria, 2011; Aron, 2000; Levchenko, 2007) as well as at the regional level (Tabellini, 2010; Rodríguez-Pose \& Di Cataldo, 2015; Ketterer \& Rodríguez-Pose, 2016). The quality of institutions also influences micro variables such as firm performance (Dollar et al., 2005; Lasagni et al., 2015; Aiello et al., 2014; Manzocchi et al., 2014).

Recent studies indicate that there might be a significant difference in the macro- and micro-impacts of institutional quality: better institutional quality that may have beneficial macro-implications, may not necessarily have positive implications for firm performance (Bhaumik \& Dimova, 2014). Consider, for instance, an indicator of weak institutional quality such as corruption. For firms, corruption increases the cost of doing business as well as the transaction costs, since implicit contracts based on bribes can be renegotiated ex post. For society as a whole, however, the incidence and the impact of corruption depend on the institutional environment prevailing in a given country, as represented by other public governance indicators (Aidt, 2009; OECD, 2015). Thus, the proper level of analysis to test whether the regional institutional environment affects productivity is to focus on firms. Relationships that are observed for groups, do not necessarily hold for individuals, this is known as the fallacy of 'the wrong level' (Jones, 1991) (Note 1). Multilevel models operate at more than one level so that a single model can handle simultaneously the micro-scale of individuals and the macro-scale of places, thereby overcoming the fallacy of 'the wrong level'. Moreover, the multilevel approach controls for spatial dependence and models the variability at each level, so that individuals belonging to a given group are more alike than a random sample. All these arguments support the choice of the multilevel approach for analysing the relationship between the quality of regional government and firm performance, measured by TFP.

In this paper, the effect on productivity of the quality of regional government is investigated by using firm-level 
data in a multi-country context. The analysis is, indeed, based on comparable cross-country data of manufacturing firms operating in seven EU countries, Austria, France, Germany, Hungary, Italy, Spain and the United Kingdom.

Improved institutional quality has recently been emphasized as one of the principal objectives of the EU under the general framework of sustainable development and in the regional policy framework. Researchers have demonstrated that while integration in the EU to date has promoted inter-national convergence, sub-national inter-regional inequalities have tended to increase. One of the reasons could be the persistence of institutional differences between regions despite integration (Farole et al., 2011; Charron et al., 2014). The so-called Europe 2020 growth strategy (European Commission, 2010) recognises that countries with a better quality of government also have a better performance and considers high quality institutions as complementary to a process of economic growth driven by innovation. Regions with a poor institutional environment are ineffective in supporting or assimilating knowledge and innovation. Institutions are a central ingredient in the current discussion on policies for enhancing economic growth in the EU to recover from the ongoing economic and financial crises (Barbosa \& Faria, 2011). Previous studies have demonstrated how institutions shape the return of economic policy at the regional level in Europe and, also, the importance of government quality as a moderator of the efficiency of the spending of Structural and Cohesion Funds: in many of the regions receiving these resources, further improvements in economic growth would require massive amounts of additional investment, unless the quality of government is significantly enhanced (Rodríguez-Pose \& Garcilazo, 2015). The problem of regional disparities in term of productivity and institutional quality has become more pressing with the Eurozone crisis. Fingleton et al (2015) have shown how a common contractionary shock across the Eurozone has its biggest impact on the most geographically isolated regions, which are precisely those areas suffering the most acute sovereign debt crisis, as well as being the regions with the lowest productivity in the EU. Understanding regional disparities in productivity is, thus, of the greatest importance in the ongoing debate about the Euro and its future.

Firm data used in this paper come from the 'European Firms in a Global Economy: internal policies for external competitiveness' (EFIGE) project (Altomonte \& Aquilante, 2012). Data for the regional 'quality of government' refer to the European Quality of Government Index (EQI).

To the best of the author's knowledge, this is the first paper that analyses, in a multi-country context, the effect on firm TFP of the within-country quality of government.

In the econometric specification, the 2008-value of TFP depends on key-characteristics of firm performance, on the variable of interest, the indicator of the quality of government, and on control variables at the regional level that, according to the theoretical and empirical literature, may affect firms' economic performance. As expected, the results show the importance of firm-specific determinants of TFP. However, they also indicate that the context in which firms operate plays a role in determining individual TFP: being located in a region with high level of R\&D and good infrastructure is correlated positively with the firm's TFP. As far as the specific scope of the paper is concerned, the results provide evidence that the quality of regional government has a positive effect on a firm's TFP. This is in line with previous research on the role of institutions at regional level that underlines their importance for economic growth (Tabellini, 2010; Ketterer \& Rodríguez-Pose, 2016), the capacity of regions to innovate (Rodríguez-Pose \& Di Cataldo, 2015) and productivity (Lasagni et al, 2015; Aiello et al., 2014; Manzocchi et al., 2014). On the contrary, the finding contradicts the hypothesis that institutional differences within a country do not matter for economic performance (Gennaioli et al., 2013). One of the main concerns in estimating the effect of the quality of regional government on firm performance is the issue of endogeneity. The attempts made to address this problem confirm the positive and significant impact of the quality of regional institutions on firm performance.

\section{Quality of Institutions at Regional Level and Economic Performance: A Brief Overview}

Institutions are the rules of the game in a society, i.e. the set of fundamental political, social, and legal rules that shape the strategic behaviours and outcomes of firms (North, 1990). Efficient institutions reduce transaction costs and the cost of enforcing contracts and they facilitate transactions with a positive effect on economic performance. Moreover, one would expect high quality institutions to provide agents with incentives for productive effort rather than socially costly rent-seeking activities or predation. A substantial body of cross-country literature documents a close correlation between institutions and development (see Jütting, 2003 and Aron, 2000, for a critical review). Most research on institutions and economic performance has country-level indicators (among others, Acemoglu et al., 2001; Barbarosa \& Faria, 2011; Hall \& Jones, 1999) while few focus on within-country institutional differences and economic performance. The use of national-level data assumes 
that the quality of institutions is the same across locations within a given country. Yet, in the case of EU, Charron et al (2014) demonstrate that there are notable within-country variations as regards local governance.

Several studies, using different measurements, demonstrate the importance of the quality of the local institutional environment on economic performance. In his seminal work, Putnam (1993) focuses on the importance of 'civic community' in developing successful institutions. He applies his theoretical framework to the South of Italy, underling how the pronounced differences in social capital between Northern and Southern Italy contribute to explaining the economic backwardness of the South (Helliwell \& Putnam, 1995). After controlling for country fixed effects, regional education and past urbanization rates, Tabellini (2010) finds that less trust and respect for others and less confidence in the individual are associated with lower per capita output and slower growth rates in 68 regions of eight European countries. Ketterer and Rodríguez-Pose (2016) and Rodríguez-Pose and Di Cataldo (2015) both use the same indicator as this paper, the EQI. In Ketterer and Rodríguez-Pose (2016), the quality of regional government, especially government effectiveness and the fight against corruption, emerges as a fundamental driver of economic performance across EU while geographical factors exert a much weaker influence on economic growth. For Rodríguez-Pose and Di Cataldo (2015) there is evidence of a link between the quality of government and the capacity of regions to innovate. Gennaioli et al. (2013) in the case of more than 1,500 regions in 110 countries find that regional education, geography and higher natural resource endowments influence per capita income positively, but regional education account for a large share of within-country variation in per capita income. On the contrary, institutions do not help to explain regional differences in per capita income. According to the authors, while some institutions and culture may matter at the national level, they do not help to explain the wide income differences within countries.

A number of firm-level studies have been carried out in the past few years, assessing the effects of the institutional environment on firm performance. Some use, as measure of the quality of institutions, the individual evaluation of the constraints for business as reported by the managers of the interviewed firms. For example, using firm-level data of the garment sector on mostly Asian developing economies, Dollar et al. (2005) find that cross-country differences in investment climate as perceived by managers do affect firm performance, even after controlling for country fixed effects; on the contrary, Commander and Svejnar (2011) show that in the case of transition economies of Central and Eastern Europe, country fixed effects matter for firm performance, but that differences in the business environment observed by top managers do not. On the other hand, Bhaumik and Dimova (2014) demonstrate, in the case of nine developing countries that certain institutions, such as restrictive labour market regulations, considered bad for economic growth might be beneficial for production efficiency, whereas a good business environment, which is considered beneficial for economic growth, might have an adverse impact on production efficiency. These results suggest that there might be significant differences in the macro- and micro-impacts of institutional quality, so that the classification of institutions into 'good' and 'bad' might depend on the level of analysis.

Few studies have pooled together firm-level data and measures of sub-national quality of institutions and the ones that have, focus on one country only (Lasagni et al., 2014; Aiello et al., 2014; Manzocchi et al., 2014). Lasagni et al. (2015) evaluate the impact of the institutional quality, measured by the Institutional Quality Index for Italian provinces (NUTS 3) built by Nifo andVecchione (2014), on TFP. They find that institutional quality at a local level does matter, as it proves to be one of the main drivers of productivity differentials. Similar results have been found by Manzocchi et al. (2014) and Aiello et al. (2014). Both studies aim to disentangle internal from external productivity drivers but they use different methodologies and, also, different indicators. Manzocchi et al (2014) use a two-step procedure for extracting fixed effects for home counties of the firms (stage one) and regressing them upon an indicator of social capital and of criminal incidence (stage two). Aiello et al. (2014) use a multilevel approach and consider the Italian regions and an indicator of public administration efficiency.

\section{Data}

The empirical analysis is based on the EU-EFIGE/Bruegel-UniCredit dataset (EFIGE dataset in short). The dataset contains data from a survey, carried out in 2010 and coordinated by Bruegel that provides comparable cross-country data of around 15 thousand manufacturing firms in seven European countries (Austria, France, Germany, Hungary, Italy, Spain and the United Kingdom) (Note 2). Data refers mostly to the 2008.

The survey data have been integrated with the balance sheets of firms from Amadeus database managed by Bureau van Dijk. These have been used to calculate the TFP by the researchers involved in the EFIGE project by applying the Levinsohn and Petrin (2003) approach. The estimated TFP for 2008 is used as measure of firm performance in this paper. When matching the EFIGE survey with the Amadeus archive, the sample decreases by about $50 \%$ because of the many missing-values in Amadeus related to the variables needed to estimate the 
production function from which the TFP is retrieved (for details, see Altomonte \& Aquilante, 2012). In what follows the results have to be understood as referring to the sample EFIGE-AMEDEUS formed by 7,239 European firms, the majority of which in France, Spain and Italy (see Appendix A).

The main independent variable of interest is the quality of regional government. This is measured considering the European 'quality of government' indicator (EQI) at regional level provided by Charron et al (2014) based on a survey, carried out in December 2009, in order to measure the perception of the quality, impartiality and level of corruption in services provided by local authorities in Europe. These three pillars are averaged together to form the final figure for each region. In particular, the regional QoG score for each country is aggregated by weighting each region's score by their share of the national population. This mean score is subtracted from each regional QoG score and the obtained value shows if the region is above or below the national average and to what extent. This figure is then added to the national level of the World Bank Governance Indicator (WGI), so each region has an adjusted score, centered on the WGI (the reference year of WGI is 2008). The QoG is standardized for the EU-27 sample so that the mean is zero with a standard deviation of one, thereby obtaining the European Quality Index. In this study the EQI indicator and its components for the 93 regions of the EFIGE seven countries are considered.

We control for a number of important independent variables at firm and regional level (see Appendix B). The choice of the variables at firm level has been made in accordance with previous literature and their expected effects are briefly outlined. First, Human Capital is proxied by a dummy variable taking the value of one if, at firm level, the share of graduate workers is higher than the national average for the labor force overall. Qualified employees are expected to influence TFP positively since they provide a firm with the ability not only to innovate, but also to absorb knowledge from other firms (Cohen \& Levinthal, 1990; Griliches, 2000). The second dummy, Innovator, is unity if the firm has introduced at least one innovation (product, process or organizational innovation) during the period surveyed and zero otherwise with the expectation that a firm's performance improves as a result of its propensity for innovation (Mohnen \& Hall, 2013). Another firm characteristic considered is whether the firm is part of a group, as membership can provide access to more resources and knowledge that ultimately affect the individual firm's ability to innovate, thereby impacting on TFP. In particular, two dummy variables are considered to distinguish between national (National group) and foreign (Foreign group) groups. Firms belonging to foreign groups are expected to be more productive since they can capitalize on knowledge accumulated by parent companies abroad and from the advantages of vertical and/or horizontal integration (Weche, 2013). The model includes the dummy Family Management, which is unity if the proportion of managers related to the controlling family is higher than the national average, in order to take into account the possibility that TFP differs between family-managed firms and non-family managed firms (see Schulze \& Gedajlovich, 2010). The effect of family management is not certain, as the evidence is mixed (Rutherford et al., 2008). Furthermore, one of the regularities relating to productivity is the positive link between productivity and exports (ISGEP, 2008). Hence, a dummy taking the value of one if the firm is an exporter in 2008 or before 2008 is included. Regressions also include two dummy variables to control for size effect, one referring to medium-sized (Medium) firms (50-250 employees) and the other to large-sized (Large) firms (more than 250 employees), while small firms represent the control group.

In order to control for the characteristics of the regional economic system, two regional variables are included. They are total intramural R\&D expenditure (Euro per inhabitant) and infrastructure density defined by motorway kilometers standardized by total regional area (Kilometers per $1000 \mathrm{~km}^{2}$ ). The first indicator is meant to capture the ability of a region to create innovation and convert knowledge spillovers into innovative capacity, thus increasing productivity. Therefore, a positive effect of this variable on TFP is expected. The second indicator is a proxy for infrastructure considered by economic theory at the root of differences in productivity. Regions with higher stock of infrastructure are expected to show higher levels of TFP. Eurostat's region database is the source for the regional control variables and the value refers to the year 2007.

\section{Methods}

The objective of the paper is to analyse, in a multi-country context, the effect on firm TFP of the quality of government at regional level. To achieve this objective microdata are used and the firm represents the unit of analysis. However, firms can be nested within regions and regions within countries, so the data are inherently clustered. With such a structure, it is likely that the firms operating within a particular geographic area are more similar to each other than a randomly selected group of firms would be. Such similarity may be due to the circumstance that they share the same external environment but also to reciprocal influence. This can result in correlated error terms among the individuals within a particular group and, thus, the assumption of independence of OLS estimation is violated, resulting in downwardly biased standard error estimates and large test statistics. 
By relaxing this assumption, multilevel modeling provides more statistically reliable estimates than those ignoring the hierarchical nature of the data. This technique explicitly models the within-group homogeneity of errors by allowing the estimation of error terms for both the individual and the group. In addition to providing more appropriate significance tests, multilevel models have the ability to simultaneously examine the effects of variables at both individual and group levels. Indeed, in multilevel analysis, variables at different levels are not simply added to the single-level equation, but are linked together in ways that make the simultaneous existence of distinct level-one and level-two equations explicit. Hence, level-two factors are used not just as independent variables to explain variability in a level-one dependent variable, but also to explain variability in random intercept (Note 3).

The specification adopted in this paper may be expressed as follows:

$$
y_{i j}=\beta_{0 j}+\sum_{v=1}^{k} \beta_{v} X_{v i j}+u_{0 j}+e_{i j}
$$

where $\mathrm{y}_{i j}$ is the 2008-value of TFP (in logarithm) of the $i$-th firm operating in region $j, X$ represents a variable measured at firm level, $\beta_{0 j}$ is the intercept that differs across level-2 units, $e_{i j}$ is the random error term with zero mean and variance $\sigma_{e}^{2}$. The specification used is a random intercept model, that is:

$$
\beta_{0 j}=\gamma_{00}+\sum_{q=1}^{h} \omega_{q} R_{q j}+u_{0 j}
$$

In so doing, $\beta_{0 j}$ differs across groups, i.e. regions, and depends on $R_{j}$, a set of variables defined at regional level, while $u_{0 j}$ is the random error term defined at the group level with zero mean and assumed to be independent of $e_{i j}$. Moreover, $X_{i j}$ and $R_{j}$ are assumed to be uncorrelated with the error terms, $e_{i j}$ and $u_{0 j}$. The random component $u_{0 j}$ captures variability in the intercept across clusters, while the fixed component $\gamma_{00}$ is a weighted average of the intercept across all clusters.

The combining of micro (eq. 1) and macro models (eq. 2) produces the specification adopted in this paper:

$$
y_{i j}=\gamma_{00}+\sum_{v=1}^{k} \beta_{v} X_{v i j}+\sum_{q=1}^{3} \omega_{q} R_{q i}+\sum_{p=1}^{10} \lambda_{p} S_{p i}+\sum_{c=1}^{6} \eta_{c} C_{c i}+u_{0 j}+e_{i j}
$$

In equation (3) dummies for countries $(C)$ and sectors $(S)$ are included to treat them as fixed effects instead of source of randomness in intercepts since the number of groups (7 and 11, respectively) are too few (Note 4).

\section{Results of the Analysis}

\subsection{Main Results}

The results are in table 1 . Column 1 refers to the empty model. The likelihood-ratio test compares the empty model with the standard OLS regression. If the null hypothesis is true, OLS can be used instead of a variance-components model. The test is highly significant and indicates that the intercept should be considered as a group-by-group variant coefficient. The evidence in favor of the multilevel approach holds for each model considered in table 1 (Note 5).

As regards firm characteristics, except for exporter, all other variables have a significant coefficient. In line with expectations and the results of previous literature, a firm that uses more human capital, that innovates or belongs to a group shows higher productivity. Moreover, consistent with previous evidence, the TFP is higher for medium-sized firms and even higher for large enterprises (Note 6). As regards the variable Family Management, family involvement in firm management seems to be negatively related to TFP for our sample. Finally, no significant association between internationalization and TFP has been found, in contrast with the literature showing that exporters self-select and over-perform (ISGEP, 2008).

The relationship between the control variables at regional level and TFP is as expected: firms located in a region with high level of R\&D and good infrastructure show higher levels of TFP. The first result is consistent with Crescenzi \& Rodríguez-Pose (2012) but not the second one. Crescenzi \& Rodríguez-Pose (2012), considering 120 regions in the EU during the period 1990-2004, provide evidence that transport infrastructure endowment is a relatively poor predictor of regional economic growth while, by contrast, local R\&D, social conditions, and migration are much better predictors of economic performance. 
Table 1 . TFP 2008 and the quality of regional governement

\begin{tabular}{|c|c|c|c|c|c|c|c|}
\hline & (1) & (2) & $(3)$ & $(4)$ & $(5)$ & $(6)$ & $(7)^{a}$ \\
\hline Constant & $\begin{array}{c}-0.075 * * * \\
(-3.95)\end{array}$ & $\begin{array}{c}-0.570 * * * \\
(-7.24)\end{array}$ & $\begin{array}{c}-0.526 * * * \\
(-7.07)\end{array}$ & $\begin{array}{c}-0.540 * * * \\
(-6.54)\end{array}$ & $\begin{array}{c}-0.543 * * * \\
(-7.30)\end{array}$ & $\begin{array}{c}-0.761 * * * \\
(-10.19)\end{array}$ & $\begin{array}{c}-0.497 * * * \\
(-7.22)\end{array}$ \\
\hline \multicolumn{8}{|l|}{ Fixed effects } \\
\hline Medium & & $\begin{array}{c}0.194 * * * \\
(15.79)\end{array}$ & $\begin{array}{c}0.194 * * * \\
(15.79)\end{array}$ & $\begin{array}{c}0.194 * * * \\
(15.81)\end{array}$ & $\begin{array}{c}0.194 * * * \\
(15.78)\end{array}$ & $\begin{array}{c}0.194 * * * \\
(15.79)\end{array}$ & $\begin{array}{c}0.192 * * * \\
(14.14)\end{array}$ \\
\hline Large & & $\begin{array}{c}0.426 * * * \\
(22.97)\end{array}$ & $\begin{array}{c}0.426 * * * \\
(22.98)\end{array}$ & $\begin{array}{c}0.426 * * * \\
(22.97)\end{array}$ & $\begin{array}{c}0.425 * * * \\
(22.94)\end{array}$ & $\begin{array}{c}0.426 * * * \\
(22.97)\end{array}$ & $\begin{array}{c}0.455^{* * * *} \\
(20.08)\end{array}$ \\
\hline Family management & & $\begin{array}{c}-0.063^{* * *} \\
(-5.64)\end{array}$ & $\begin{array}{c}-0.063 * * * \\
(-5.64)\end{array}$ & $\begin{array}{c}-0.063 * * * \\
(-5.63)\end{array}$ & $\begin{array}{c}-0.063 * * * \\
(-5.64)\end{array}$ & $\begin{array}{c}-0.063 * * * \\
(-5.64)\end{array}$ & $\begin{array}{c}-0.062 * * * \\
(-5.49)\end{array}$ \\
\hline National group & & $\begin{array}{c}0.0847 \text { *** } \\
(6.50)\end{array}$ & $\begin{array}{c}0.0847 * * * \\
(6.50)\end{array}$ & $\begin{array}{c}0.0848^{* * * *} \\
(6.51)\end{array}$ & $\begin{array}{c}0.0849 * * * \\
(6.52)\end{array}$ & $\begin{array}{c}0.0847 * * * \\
(6.50)\end{array}$ & $\begin{array}{c}0.0799 * * * \\
(5.67)\end{array}$ \\
\hline Foreign group & & $\begin{array}{c}0.197 * * * \\
(11.97)\end{array}$ & $\begin{array}{c}0.196 * * * \\
(11.96)\end{array}$ & $\begin{array}{c}0.196 * * * \\
(11.96)\end{array}$ & $\begin{array}{c}0.197 * * * \\
(11.99)\end{array}$ & $\begin{array}{c}0.197 * * * \\
(11.97)\end{array}$ & $\begin{array}{c}0.219 * * * \\
(10.86)\end{array}$ \\
\hline Innovator & & $\begin{array}{c}0.0216^{* * *} \\
(2.25)\end{array}$ & $\begin{array}{c}0.0216^{* *} \\
(2.26)\end{array}$ & $\begin{array}{c}0.0217^{* *} \\
(2.27)\end{array}$ & $\begin{array}{c}0.0216^{* *} \\
(2.26)\end{array}$ & $\begin{array}{c}0.0216^{* *} \\
(2.25)\end{array}$ & $\begin{array}{c}0.0240^{* *} \\
(2.37)\end{array}$ \\
\hline Human capital & & $\begin{array}{c}0.0485^{* * *} \\
(4.90)\end{array}$ & $\begin{array}{c}0.0487 * * * \\
(4.92)\end{array}$ & $\begin{array}{c}0.0479 * * * \\
(4.84)\end{array}$ & $\begin{array}{c}0.0486^{* * *} \\
(4.91)\end{array}$ & $\begin{array}{c}0.0485^{* * *} \\
(4.90)\end{array}$ & $\begin{array}{c}0.0503 * * * \\
(4.87)\end{array}$ \\
\hline Exporter & & $\begin{array}{c}0.0114 \\
(1.12)\end{array}$ & $\begin{array}{c}0.0112 \\
(1.10)\end{array}$ & $\begin{array}{r}0.0121 \\
(1.18)\end{array}$ & $\begin{array}{c}0.0114 \\
(1.12)\end{array}$ & $\begin{array}{c}0.0114 \\
(1.12)\end{array}$ & $\begin{array}{c}0.00679 \\
(0.64)\end{array}$ \\
\hline Country dummies & NO & YES & YES & YES & YES & YES & YES \\
\hline \multicolumn{8}{|l|}{ Level 2: Regions } \\
\hline Federalism $(1 / 0)$ & & & & & & $\begin{array}{c}0.190 * * * \\
(5.06)\end{array}$ & \\
\hline EQI & & $\begin{array}{c}0.0531 \text { *** } \\
(2.58)\end{array}$ & & & & $\begin{array}{c}0.0531 * * * \\
(2.58)\end{array}$ & $\begin{array}{c}0.0598 * * * \\
(2.72)\end{array}$ \\
\hline Quality & & & $\begin{array}{c}0.0503 * * * \\
(2.73)\end{array}$ & & & & \\
\hline Impartiality & & & & $\begin{array}{c}0.0293 \\
(1.26)\end{array}$ & & & \\
\hline Corruption & & & & & $\begin{array}{c}0.0680^{* * * *} \\
(2.94)\end{array}$ & & \\
\hline $\mathrm{R} \& \mathrm{D}(\ln )$ & & $\begin{array}{c}0.0318^{* * *} \\
(3.68)\end{array}$ & $\begin{array}{c}0.0326 * * * \\
(3.77)\end{array}$ & $\begin{array}{c}0.0318^{* * *} \\
(3.54)\end{array}$ & $\begin{array}{c}0.0283^{* * *} \\
(3.33)\end{array}$ & $\begin{array}{c}0.0318^{* * *} \\
(3.68)\end{array}$ & $\begin{array}{c}0.0263 * * * \\
(2.58)\end{array}$ \\
\hline Motorway (ln) & & $\begin{array}{c}0.0408^{* * *} * \\
(2.76)\end{array}$ & $\begin{array}{c}0.0382 * * * \\
(2.58)\end{array}$ & $\begin{array}{c}0.0400 * * * \\
(2.64)\end{array}$ & $\begin{array}{c}0.0435^{* * *} \\
(2.96)\end{array}$ & $\begin{array}{c}0.0408^{* * *} \\
(2.76)\end{array}$ & $\begin{array}{c}0.0444 * * \\
(2.57)\end{array}$ \\
\hline \multicolumn{8}{|l|}{ Random-Effects } \\
\hline \multicolumn{8}{|l|}{ Variance } \\
\hline Regions & 0.028 & 0.004 & 0.004 & 0.004 & 0.003 & 0.004 & 0.004 \\
\hline Firms & 0.170 & 0.136 & 0.136 & 0.136 & 0.136 & 0.137 & 0.131 \\
\hline LR test & 741.0 & 115.4 & 117.4 & 124.2 & 100.3 & 115.6 & 122.4 \\
\hline Log restricted-likelihood & -3968.1 & -3165.6 & -3171.7 & -3174.3 & -3170.9 & -3172.0 & -2563.2 \\
\hline Number of observations & 7239 & 7239 & 7239 & 7239 & 7239 & 7239 & 6116 \\
\hline
\end{tabular}

Note. In parentheses, $\mathrm{t}$-values. Level of significance: $* * * 1 \%, * * 5 \%$. (a) Sample: France-Italy-Spain.

As far as the specific scope of this paper is concerned, column 2 shows that the quality of regional government has a positive connection with firm TFP (Note 7). Focusing on the studies that analyse the role of institutions at regional level, this finding is in line with previous research underscoring their importance for economic growth (Tabellini, 2010; Ketterer \& Rodríguez-Pose, 2016), regional innovation (Rodríguez-Pose \& Di Cataldo, 2015) and productivity (Lasagni et al., 2015; Aiello et al., 2014; Manzocchi et al., 2014). On the contrary, the result contradicts the hypothesis that within country institutional differences do not matter for economic performance (Gennaioli et al., 2013). 
Considering the individual components of EQI, it is possible to assess which aspects of the quality of government are important for TFP. The results show that the corruption, which accounts, by construction, higher values for lower levels of corruption (column 5), and quality of services (column 3) are positively related to TFP, while the evidence is inconclusive for the impartiality index (column 4). Efficient and non-bureaucratic public service provision as well as a low level of local corruption seem to be important factors for good firm performance, as already evidenced by Ketterer and Rodríguez-Pose (2016) for economic growth and Rodríguez-Pose and Di Cataldo (2015) for regional innovation in Europe.

To check robustness, the possibility that QoG indicator may capture aspects related to the nature of state governance is investigated. In fact, supporters of federalism believe that devolving resources and authority from national to subnational government levels may stimulate more efficient and better-targeted policies. The positive coefficients for EQI could, thus, reflect the effect of greater regional autonomy and not the quality of government per se. For this reason, eq. (3) is augmented by a dummy variable for federal and semi-federal states, Federalism (Note 8). The coefficient of this variable appears positive and significant (columns 6), but the coefficient of EQI is unaffected.

One shortcoming of the dataset used in this paper is the loss of observations related to the matching procedure of the EFIGE survey with balance-sheet data. As a second robustness test, only countries that, due to more comprehensive balance sheet data, have a larger number of TFP-observations at the firm level, i.e. France, Italy, and Spain (see appendix A), are considered. The results are confirmed for EQI (see table 1, column 7) and sub-indicators, but, in this case, also the coefficient of impartiality appears positive and significant at 5\% (results available upon request).

\subsection{Endogeneity Issues}

The stochastic part of multilevel models is more structured than single-level models, so the phenomenon of endogeneity is more complex. Indeed, as multilevel models have one error term at each hierarchical level, the problem of endogeneity may concern error terms at each level (Grilli \& Rampichini, 2006).

Addressing the endogeneity issues on the basis of cross-section data is tricky. In this section various ways to address and reduce such problems are discussed. The first type of endogeneity problem is the so-called level two endogeneity. This may occur when the random effects at level-two are correlated with level-one covariates. However, it is possible to devise a simple remedy to overcome this. The correlation between the lower level predictor variables and higher level error terms can be removed by including the group-level means of the lower level variables, a procedure known as the Mundlak (1978) correction (table 2, Panel A). The results are confirmed for EQI, quality and corruption even if the significance level is lower (5\% instead of $1 \%$ ). The coefficient of the impartially indicator remains not statistically significant.

Another form of endogeneity may arise when level two covariates are correlated with error terms. In the specific case of this paper, endogeneity may arise when the regions with a better quality of regional government attract the more productive firms or when possible channels of reverse causality exist where QoG is high because productive firms are located close by. In order to overcome this problem, an instrumental variable approach is adopted using the Spencer and Fielding (2000) procedure that adapts this technique to cover multilevel random effects models for obtaining consistent parameter estimates. In the first step of the procedure, the fixed effect parameters are estimated by instrumenting the endogenous variable providing consistent estimates of the fixed coefficients in equation (3) but not adequate estimates of their standard errors. Next, the standard errors are estimated by imposing the restriction that the fixed parameters equal the estimates obtained in the first step (see Spencer \& Fielding, 2000, for more information) (Note 9).

Three instrumental variables are taken in consideration. First, following Ketterer and Rodríguez-Pose (2016), two regional historical variables are used as instruments for the quality of regional government. The first is a dummy variable that takes the value one if the region was part of the Roman Empire under Caeser in $49 \mathrm{BC}$. The second takes a value of one if the region was part of Charlemagne's empire and/or represented a tributary territory at the time of the Emperor's death in $814 \mathrm{AD}$ (Note 10). In the history of Europe, the Roman and Carolingian Empire represent precursors of 'modern' systems of government (Note 11). The fact that a region was, at one time, part of the Roman or Carolingian Empire will probably have had a certain influence on the formation and development of its institutional framework. Thus, exposure to these systems of governance may be used as instrument for current institutions (Ketterer \& Rodríguez-Pose, 2016). As in Camussi and Mancini (2016), the other instrumental variable is the percentage of public workers on total employment back in time (Note 12). This variable can be considered as a proxy of the historical level of resources dedicated by the region to the production of public services. More resources may translate in a better quality of public sector services or, 
on the contrary, in a greater division in the provision of services with complementarity functions that may foster bribery and inefficiency (Tsanana et al., 2016). It is reasonable to assume that historical variables and the production of public services back in time are linked to the quality of regional government indicators but not to the 2008 firm TFP. The F-statistics on the excluded instruments show that they are not weak and the Sargan test that they are good instruments (Note 13). In Table 2, Panel B reports the results obtained with the instrumental variable estimation procedure. The instrumental variable approach provides consistent estimates which confirm the positive impact of all the QoG indicators on firm performance, including the impartiality indicator (at 5\% level of significance).

Finally, another approach to minimize the cause of endogeneity is the use of lagged values. Recently Bruegel has updated the EFIGE dataset, by extending the panel-level balance sheet data until the year 2014, and made available the estimation of TFP for the year 2014. This update allows using TFP for 2014 as dependent variable instead of TFP 2008 and the indicators of the quality of regional institutions as lagged values. Lagged values help to reduce the endogeneity arising from possible simultaneous feedbacks from the quality of regional institutions and TFP (Note 14). Nevertheless, the extension of the panel-level balance sheet data has meant a further loss of observations (see Appendix A). Considering this further reduction in the sample size, the analysis is restricted to the three countries that have a larger number of TFP-observations at firm level, already considered in column 7 of table 1, France, Italy and Spain (Nota 15). For the QoG indicators the findings confirm the IV estimates (table 2, Panel C) (Note 16).

Table 2. TFP and the quality of regional governement: endogeneity issues

\begin{tabular}{|c|c|c|c|c|}
\hline \multirow[b]{2}{*}{ Constant } & \multicolumn{4}{|c|}{ Panel A: Mundlak correction } \\
\hline & $\begin{array}{c}-0.523 * * * \\
(-3.62)\end{array}$ & $\begin{array}{c}-0.486^{* * *} \\
(-3.28)\end{array}$ & $\begin{array}{c}-0.57 * * * \\
(-3.92)\end{array}$ & $\begin{array}{c}-0.485 * * * \\
(-3.34)\end{array}$ \\
\hline Firms Characteristics & YES & YES & YES & YES \\
\hline EQI & $\begin{array}{c}0.046^{* *} \\
(1.96)\end{array}$ & & & \\
\hline Quality & & $\begin{array}{c}0.045^{* *} \\
(2.15)\end{array}$ & & \\
\hline Impartiality & & & $\begin{array}{l}0.014 \\
(0.56)\end{array}$ & \\
\hline Fight to Corruption & & & & $\begin{array}{c}0.062 * * \\
(2.47)\end{array}$ \\
\hline $\mathrm{R} \& \mathrm{D}(\ln )$ & $\begin{array}{c}0.031 * * * \\
(3.33)\end{array}$ & $\begin{array}{c}0.032 * * * \\
(3.40)\end{array}$ & $\begin{array}{c}0.028 * * * \\
(2.80)\end{array}$ & $\begin{array}{c}0.029 * * * \\
(3.21)\end{array}$ \\
\hline Motorway (ln) & $\begin{array}{c}0.045 * * * \\
(2.87)\end{array}$ & $\begin{array}{c}0.044 * * * \\
(2.82)\end{array}$ & $\begin{array}{c}0.043 * * * \\
(2.67)\end{array}$ & $\begin{array}{c}0.047 * * * \\
(3.04)\end{array}$ \\
\hline Mundlak Correction & YES & YES & YES & YES \\
\hline \multicolumn{5}{|l|}{ Random-Effects } \\
\hline \multicolumn{5}{|l|}{ Variance } \\
\hline Regions & 0.003 & 0.003 & 0.003 & 0.003 \\
\hline Firms & 0.136 & 0.136 & 0.136 & 0.136 \\
\hline Total & 0.139 & 0.139 & 0.139 & 0.139 \\
\hline Number of observations & 7239 & 7239 & 7239 & 7239 \\
\hline & \multicolumn{4}{|c|}{ Panel B: IV (a) } \\
\hline Constant & $\begin{array}{c}-0.481 * * * \\
(-3.36)\end{array}$ & $\begin{array}{c}-0.435 * * * \\
(-2.94)\end{array}$ & $\begin{array}{c}-0.56 * * * \\
(-3.50)\end{array}$ & $\begin{array}{c}-0.428 * * * \\
(2.91)\end{array}$ \\
\hline Firms Characteristics & YES & YES & YES & YES \\
\hline EQI & $\begin{array}{c}0.123 * * * \\
(2.80)\end{array}$ & & & \\
\hline Quality & & $\begin{array}{c}0.098 * * * \\
(2.72)\end{array}$ & & \\
\hline Impartiality & & & $\begin{array}{c}0.178^{* *} \\
(2.28)\end{array}$ & \\
\hline Fight to Corruption & & & & $\begin{array}{c}0.127 * * * \\
(2.70)\end{array}$ \\
\hline
\end{tabular}




\begin{tabular}{|c|c|c|c|c|}
\hline $\mathrm{R} \& \mathrm{D}(\ln )$ & $\begin{array}{c}0.041 * * * \\
(4.10)\end{array}$ & $\begin{array}{c}0.040 * * * \\
(4.00)\end{array}$ & $\begin{array}{c}0.049 * * * \\
(3.26)\end{array}$ & $\begin{array}{c}0.031 \text { *** } \\
(3.87)\end{array}$ \\
\hline Motorway (ln) & $\begin{array}{c}0.051 * * * \\
(3.40)\end{array}$ & $\begin{array}{c}0.048 \text { *** } \\
(3.43)\end{array}$ & $\begin{array}{c}0.051 * * * \\
(2.83)\end{array}$ & $\begin{array}{c}0.052 * * * \\
(3.71)\end{array}$ \\
\hline Mundlak Correction & YES & YES & YES & YES \\
\hline \multicolumn{5}{|l|}{ Random-Effects } \\
\hline \multicolumn{5}{|l|}{ Variance } \\
\hline Regions & 0.002 & 0.002 & 0.005 & 0.002 \\
\hline Firms & 0.136 & 0.136 & 0.136 & 0.136 \\
\hline Total & 0.138 & 0.138 & 0.141 & 0.138 \\
\hline \multicolumn{5}{|l|}{ Instrumental Variables } \\
\hline Roman Empire & YES & YES & YES & YES \\
\hline Charlemagne's Empire & YES & YES & YES & YES \\
\hline$\%$ of public workers on total employment (1999) & YES & YES & YES & YES \\
\hline F- statistics on the excluded instruments & 1028.6 & 1734.3 & 580.3 & 646.64 \\
\hline Sargan test & 0.94 & 1.25 & 0.16 & 2.17 \\
\hline \multirow[t]{2}{*}{ Number of observations } & 7239 & 7239 & 7239 & 7239 \\
\hline & \multicolumn{4}{|c|}{ Panel C: TFP 2014 (France-Italy-Spain) } \\
\hline Constant & $\begin{array}{c}-0.787 * * * \\
(-7.58)\end{array}$ & $\begin{array}{c}-0.907 * * * \\
(-8.68)\end{array}$ & $\begin{array}{c}-0.848^{* * *} \\
(-8.00)\end{array}$ & $\begin{array}{c}-0.822 * * * \\
(-8.11)\end{array}$ \\
\hline Firms Characteristics & YES & YES & YES & YES \\
\hline EQI & $\begin{array}{c}0.0928 * * * \\
(2.97)\end{array}$ & & & \\
\hline Quality & & $\begin{array}{c}0.0855^{* * * *} \\
(3.04)\end{array}$ & & \\
\hline Impartiality & & & $\begin{array}{c}0.0807^{* *} \\
(2.09)\end{array}$ & \\
\hline Fight to Corruption & & & & $\begin{array}{c}0.111 * * * \\
(3.12)\end{array}$ \\
\hline $\mathrm{R} \& \mathrm{D}(\ln )$ & $\begin{array}{c}0.0202 \\
(1.35)\end{array}$ & $\begin{array}{l}0.0231 \\
(1.54)\end{array}$ & $\begin{array}{c}0.0189 \\
(1.21)\end{array}$ & $\begin{array}{c}0.0156 \\
(1.06)\end{array}$ \\
\hline Motorway (ln) & $\begin{array}{c}0.0385 \\
(1.44)\end{array}$ & $\begin{array}{l}0.0353 \\
(1.32)\end{array}$ & $\begin{array}{c}0.0400 \\
(1.46)\end{array}$ & $\begin{array}{c}0.0410 \\
(1.56)\end{array}$ \\
\hline Mundlak Correction & NO & NO & NO & NO \\
\hline Random-Effects & & & & \\
\hline Variance & & & & \\
\hline Regions & 0.007 & 0.006 & 0.008 & 0.006 \\
\hline Firms & 0.312 & 0.312 & 0.312 & 0.312 \\
\hline Total & 0.318 & 0.318 & 0.319 & 0.318 \\
\hline Number of observations & 4870 & 4870 & 4870 & 4870 \\
\hline
\end{tabular}

(a) Estimates obtained using MlwiN macro (IV) implemented by Spencer and Fielding (2000).

All model with sector and country dummies. In parentheses, t-values. Level of significance: *** $1 \%$, ** 5\%.

\section{Concluding Remarks}

Institutional quality has gained a particularly important role in the EU general framework of sustainable development and regional policy. This paper aims to analyse the effect of the quality of regional government on firm TFP in a multi-country context, considering a group of EU countries.

The unit of analysis is the firm; this represents the most appropriate level to test whether the regional institutional environment affects productivity since it overcomes the fallacy of 'the wrong level' and can also account for the difference in the macro- and micro-impacts of institutional quality. In order to disentangle internal from external productivity drivers, the multilevel approach is employed. Results refer to 2008 and show, as expected, the importance of firm-specific determinants of TFP. However, the context in which firms operate plays a role in determining individual TFP. Results show that the regional endowment of infrastructure and the investments in $R \& D$ exert a positive effect on firm performance: firms located in a region with high level of $R \& D$ and good infrastructure show higher levels of TFP. 
As far as the specific scope of this paper is concerned, the quality of regional institutions affects firm TFP positively and this result appears to be confirmed by robustness checks and the attempts made to overcome endogeneity problems.

This finding is in line with previous research underlining the importance of institutional quality at regional level and refutes the hypothesis that within country institutional differences do not matter for economic performance. The findings of this research indicate that a region with poor institutional quality is likely to be characterized by low productivity, but, as already evidenced by Rodríguez-Pose and Garcilazo (2015), this type of region may also be unable to use cohesion and other funds effectively. The risk, therefore, is that regions with low QoG may be trapped in low competitiveness and low growth. This is an important issue because existing regional inequalities already pose a threat to the cohesion of the European Union. In the current context of slow growth, high unemployment and fiscal stringency in EU countries, efforts aimed at improving the quality of local government and eradicating nepotism and corruption in the exercise of public affairs may thus represent a means to help less-favoured regions to overcome low competitiveness.

\section{Acknowledgments}

The author thanks Francesco Aiello for suggestions on the initial idea of the research. I also would like to thank the participants of the National Research University Higher School of Economics XVII April International Academic Conference (Moscow 19-22 April 2016) and the 56th ERSA congress (Vienna, 23-26 August 2016) for valuable suggestions on an earlier version of the paper. Grateful acknowledgments are also due to Bruegel (www.bruegel.org) for making available the EFIGE dataset in the version including Total Factor Productivity and for the easy access and use of the data set at Brussels. Usual disclaimer applies.

\section{References}

Acemoglu, D., Johnson, S., \& Robinson, J. A. (2001). The Colonial Origins of Comparative Development: An Empirical Investigation. The American Economic Review, 91, 1369-1401. https://doi.org/10.1257/aer.91.5.1369

Aidt, T. S. (2009). Corruption, Institutions, and economic development. Oxford Review of Economic Policy, 25, 271-291. https://doi.org/10.1093/oxrep/grp012

Aiello, F., \& Ricotta, F. (2016). Firm heterogeneity in productivity across Europe. Evidence from multilevel models. Economics of Innovation and New Technology, 25, 57-89. https://doi.org/10.1080/10438599.2015.1057001

Aiello, F., Pupo, V., \& Ricotta, F. (2014). Explaining Total Factor Productivity at Firm Level in Italy: Does Location Matter? Spatial Economic Analysis, 9, 1-20. https://doi.org/10.1080/17421772.2013.863428

Altomonte, C., \& Aquilante, T. (2012). The EU-EFIGE/Bruegel-Unicredit dataset. Bruegel Working paper 13, Brussels. Retrieved from http://bruegel.org/wp-content/uploads/imported/publications/WP_2012_13_2_.pdf

Aron J. (2000). Growth and Institutions: A Review of the Evidence. The World Bank Research Observer, 15, 1203-1228. https://doi.org/10.1093/wbro/15.1.99

Barbosa, N., \& Faria, A. P. (2011). Innovation across Europe: How Important Are Institutional Differences? Research Policy, 40, 1157-1169. https://doi.org/10.1016/j.respol.2011.05.017

Bhaumik, S. K., \& Dimova, R. (2014). Good and bad institutions: is the debate over? Cross-country firm-level evidence from the textile industry. Cambridge Journal of Economics, 38, 109-126. https://doi.org/10.1093/cje/bes089.

Charron N., Dijkstra, L., \& Lapuente, V. (2014). Regional Governance Matters: Quality of Government within $\begin{array}{lllll}\text { European Union Member States. Regional } & \text { Studies, }\end{array}$ https://doi.org/10.1080/00343404.2013.770141.

Cohen, W. M., \& Levinthal, D. A. (1990). Absorptive capacity: A new perspective of learning and innovation. Administrative Science Quarterly, 35, 128-152. https://doi.org/10.2307/2393553

Commander, S., \& Svejnar, J. (2011). Business environment, exports, ownership, and firm performance. Review of Economics and Statistics, 93, 309-337. https://doi.org/10.1162/REST_a_00135

Crescenzi, R., \& Rodríguez-Pose, A. (2012). Infrastructure and regional growth in the European Union. Papers in Regional Science, 91, 487-513. https://doi.org/10.1111/j.1435-5957.2012.00439.x

Dollar, D., Hallward-Driemeier, M., \& Mengistae, T. (2005). Investment climate and firm performance in 
developing countries. Economic Development and Cultural Change, 54, 1-31. https://doi.org/0013-0079/2005/5401-0001\$10.00

European Commission. (2010). EUROPE 2020 A strategy for smart, sustainable and inclusive growth. European Commission. Retrieved from https://www.eea.europa.eu/policy-documents/com-2010-2020-europe-2020.

Farole, T., Rodríguez-Pose, A., \& Storper, M. (2011). Cohesion Policy in the European Union: Growth, Geography, Institutions. Journal of Common Market Studies, 49, 1089-1111. https://doi.org/10.1111/j.1468-5965.2010.02161.x

Fingleton, B., Garretsen, H., \& Martin, R. (2015). Shocking aspects of monetary union: The vulnerability of regions in Euroland. Journal of Economic Geography, 15, 907-934. https://doi.org/10.1093/jeg/lbu055.

Gennaioli, N., La Porta, R., López-de-Silanes, F., \& Shleifer, A. (2013). Human capital and regional development. The Quarterly Journal of Economics, 128, 105-164. https://doi.org/10.1093/qje/qjs050.

Griliches, Z. (2000). R\&D, Education and Productivity. A Retrospective. Cambridge, MA: Harvard University Press.

Grilli, L., \& Rampichini, C. (2006). Model building issues in multilevel linear models with endogenous covariates. Proceeding of IASC-Interface-IFCS workshop, Villa Orlandi Island of Capri, Italy, 4-6 September.

Hall, R. E., \& Jones, C. I. (1999). Why do some countries produce so much more output per worker than others? Quarterly Journal of Economics, 114, 83-116. https://doi.org/10.1162/003355399555954

Helliwell, J. F., \& Putnam, R. (1995). Economic Growth and Social Capital in Italy. Eastern Economic Journal, 21, 295-307.

ISGEP, International Study Group on Exports and Productivity. (2008). Understanding Cross-Country Differences in Exporter Premia: Comparable Evidence for 14 Countries. Review of World Economics, 144, 596-635. https://doi.org/10.1007/s10290-008-0163-y

Jones, K. (1991). Multi-Level Models for geographical research. Concepts and techniques in modern Geography, Department of Geography, Portsmouth Polytechnic. Retrieved from http://www.ggy.bris.ac.uk/personal/KelvynJones/54-multi-level-models.pdf

Jütting, J. (2003). Institutions and development: A critical review. OECD Development Centre, WP n. 210.

Ketterer, T. D., \& Rodríguez-Pose, A. (2016). Institutions vs. 'first-nature' geography - What drives economic growth in Europe's regions? Papers in Regional Science. https://doi.org/10.1111/pirs.12237.

Kishlansky, M., Geary, P., \& O’Brien, P. (2003). Civilization in the West (5th ed.). New York: Prentice Hall.

Lasagni, A., Nifo, A., \& Vecchione, G. (2015). Firm productivity and institutional quality: Evidence from Italian industry. Journal of Regional Science, 1-27. doi: 10.1111/jors. 12203

Levchenko, A. A. (2007). Institutional Quality and International Trade. Review of Economic Studies, 74, 791-819. https://doi.org/10.1111/j.1467-937X.2007.00435.x

Levinsohn, J., \& Petrin, A. (2003). Estimating production functions using inputs to control for unobservables. Review of Economic Studies, 7, 317-341. https://doi.org/10.1111/1467-937X.00246

Manzocchi, S., Quintieri, B., \& Santoni, G. (2014). Internal vs. External Firm Productivity Drivers. A Study of the Italian Counties. In LUISS Lab Working Papers, Roma: LLEE Luiss.

Mariani, M. (2004). What determines technological hits? Geography versus firm competencies. Research Policy, 33, 1565-1582. https://doi.org/10.1016/j.respol.2004.08.004

Mass, J. M, \& Hox, J. J. (2004). Robustness issues in multilevel regression analysis. Statistica Neederlandica, 58, 127-137. https://doi.org/10.1046/j.0039-0402.2003.00252.x

Mohnen, P., \& Hall, B. H. (2013). Innovation and productivity: An update. Eurasian Business Review, 3, 47-65.

Mundlak, Y. (1978). On the pooling of time series and cross-sectional data. Econometrica, 46, 69-86. https://doi.org/10.2307/1913646

Nifo, A., \& Vecchione, G. (2014). Do Institutions Play a Role in Skilled Migration? The Case of Italy. Regional Studies, 48, 1628-1649. https://doi.org/10.1080/00343404.2013.835799

Nistotskaya, M., Charron, N., \& Lapuente, V. (2015). The wealth of regions: Quality of government and SMEs in 172 European regions. Environment and Planning C: Government and Policy, 33, 1125-1155. 
https://doi.org/10.1068/c13224r

North, D. C. (1990). Institutions, institutional change and economic performance. Cambridge: Harvard University Press. https://doi.org/10.1017/CBO9780511808678

OECD. (2015). Consequences of Corruption at the Sector Level and Implications for Economic Growth and Development. Paris: OECD Publishing.

Putnam, R. D. (1993). Making Democracy Work. In R. Leonardi, \& R. Y. Nanetti (Eds.), Civic Traditions in Modern Italy. Princeton, NJ: Princeton University Press.

Rodríguez-Pose, A., \& Di Cataldo, M. (2015). Quality of government and innovative performance in the regions of Europe. Journal of Economic Geography, 15, 673-706. https://doi.org/10.1093/jeg/lbu023

Rodríguez-Pose, A., \& Garcilazo, E. (2015). Quality of Government and the Returns of Investment: Examining the Impact of Cohesion Expenditure in European Regions. Regional Studies, 49, 1274-1290. https://doi.org/ 10.1080/00343404.2015.1007933

Rutherford, M., Kuratko, D., \& Holt, D. (2008). Examining the link between "familiness" and performance: Can the F-PEC untangle the family business theory jungle? Entrepreneurship Theory and Practice, 32, 1089-1109. https://doi.org/10.1111/j.1540-6520.2008.00275.x.

Schulze, W. S., \& Gedajlovic, E. R. (2010). Guest editors' introduction. Whither family business? Journal of Management Studies, 47, 191-204. https://doi.org/10.1111/j.1467-6486.2009.00887.x

Spencer, N., \& Fielding, A. (2000). An instrumental variable consistent estimation procedure to overcome the problem of endogenous variables in multilevel models. Multilevel Modelling Newsletter, 12, 4-7.

Tabellini, G. (2010). Culture and Institutions: Economic Development in the Regions of Europe. Journal of the European Economic Association, 8, 677-716. https://doi.org/10.1111/j.1542-4774.2010.tb00537.x.

Tsanana, E., Chapsa, X., \& Katrakilidis, C. (2016). Is growth corrupted or bureaucratic? Panel evidence from the enlarged EU. Applied Economics, 48, 3131-3147. https://doi.org/10.1080/00036846.2015.1136395

Weche Gelübcke, J. P. (2013). The performance of foreign affiliates in German manufacturing: Evidence from a new database. Review of World Economics, 149, 151-182. https://doi.org/10.1007/s10290-012-0142-1

\section{Notes}

Note 1 . The fallacy of the wrong level could be committed upwards or downwards. When a result obtained at an aggregate level is not confirmed after replicating the analysis on an individual basis there is ecological fallacy. In this sense, micro-founded analysis is preferable since it controls for any potential aggregation bias. On the other hand, working with micro-data leads to the opposite problem related to the absence of any link between individual-level and group-level relationships, i.e. the atomistic fallacy.

Note 2. The unit of analysis in EFIGE dataset is the firm and no plant level information is available. Results have to be interpreted considering this limit. However, it is worth noting that around $70 \%$ of the firms in the dataset are small-sized firms which are probably single-plant firms.

Note 3. The possibility to employ contextual factors to explain variability in random components is the main difference between the multilevel model and random coefficient regression.

Note 4. In the multilevel approach a key issue to be addressed concerns the sample size at any level of analysis. Indeed, the requirements of precise measurement of between-group variance impose a 'sufficient' number of clusters, more than 30 or 50 (Mass \& Hox, 2004).

Note 5. Using the same dataset and methodology, Aiello and Ricotta (2016) measure how much TFP heterogeneity is due to firm-specificities or sector membership and how much depends on localization. They demonstrate that TFP heterogeneity is largely due to firm-specific features and that country-effect is more influential than region-effect in explaining individual productivity.

Note 6. The models have been estimated also using the share of graduates on total employees as proxy of human capital, the number of employees (in log) to control for size effect and the share of employees involved in R\&D activities instead of the innovation variable. No meaningful differences were detected, however, the use of these variables would have meant the loss of up to 200 observations (results are available upon request).

Note 7. For reference, the model in column 2 of table 1 has been estimated by running a standard OLS regression, with clustered standard errors at regional level. Results are confirmed but the EQI significance decreases to $10 \%$. 
Results are available upon request.

Note 8. Federal states in the sample are Austria and Germany. Spain and Italy are coded as semifederal, and the rest are coded as unitary (see, Nistotskaya et al., 2015).

Note 9. Spencer and Fielding (2000) use MlwiN (a software package for fitting multilevel models) to write a macro, called IV, to implement this procedure, available on http://www.bristol.ac.uk/cmm/software/mlwin/download/macros.html. The models are estimated by Iterative Generalized Least Square (IGLS) algorithms. I would like to thank Neil Spencer for providing helpful suggestions about IV macro. I am also grateful to Chris Charlton for help on how to use macro in MlwiN.

Note 10. Historical dummies were built by using the historical maps available in Kishlansky et al. (2003) and in the online source www.euratlas.com.

Note 11. Ancient Rome was a Republic with a complex system of government that encompassed detailed laws and elected officials such as senators. The provinces were ruled by governors appointed by Senate and were in charge of the local army and the collection of taxes. Charlemagne created an administrative system with central and local components, with counts who supervised the royal estates and exercised jurisdiction in the county, and teams of emissaries (missi dominici) sent by the king to control the state of each county (Kishlansky et al., 2003).

Note 12. The source is the Eurostat Regional Statistics Database and the first available year, generally 1999, is considered.

Note 13. These statistics not made available in the MLwiN software have been calculated in STATA. The F-statistics by regressing the overall index and sub-indices of the quality of government on the instrumental variables with inclusion of all control variables. For the Sargan test, first the residuals of the first stage equation have been regressed upon all instruments, then the Sargan statistics is calculated by multiplying the R 2 from this regression by the sample size.

Note 14. Endogeneity issues may involve also firm-level controls, such as contemporaneous firm innovative propensity or human capital that may be endogeneous to firm TFP. The cross-section structure of data prevents the use of lagged values or firm-fixed effects to overcome this problem. However, in the estimate of TFP for 2014, the covariates at firm level refer to survey data and, thus, represent lagged values of the firm's characteristics with the effect to reduce endogeneity problems.

Note 15. The test of the presence of 2-level endogeneity in models where TFP in 2014 is used as dependent variable rejects this hypothesis. Nevertheless, when the Mundlak correction is considered in the models the findings remain largely the same (results available on request).

Note 16. As far as firm characteristics, sign and significance is confirmed for foreign group and human capital, while for the other firm characteristics the coefficients are not significant. On the contrary, the export status now appears significant but with a negative coefficient (results available on request).

\section{Appendix}

Appendix A. Distribution of firms by country

\begin{tabular}{|c|c|c|c|c|c|c|}
\hline Country & EFIGE Survey & $\%$ & EFIGE-AMADEUS & $\%$ & EFIGE-AMADEUS EXTENSION & $\%$ \\
\hline France & 2973 & 20.1 & 1568 & 21.7 & 1018 & 18.3 \\
\hline Germany & 2935 & 19.9 & 550 & 7.6 & 135 & 2.4 \\
\hline Hungary & 488 & 3.3 & 162 & 2.2 & 161 & 2.9 \\
\hline Italy & 3021 & 20.5 & 2212 & 30.6 & 2265 & 40.7 \\
\hline Spain & 2832 & 19.2 & 2336 & 32.3 & 1587 & 28.5 \\
\hline UK & 2067 & 14 & 387 & 5.3 & 329 & 5.9 \\
\hline Total & 14759 & 100 & 7239 & 100 & 5559 & 100 \\
\hline
\end{tabular}

Source: Computation on data from EU-EFIGE/Bruegel-UniCredit data set. 
Appendix B. Summary statistics of variables, data sources and expected effect

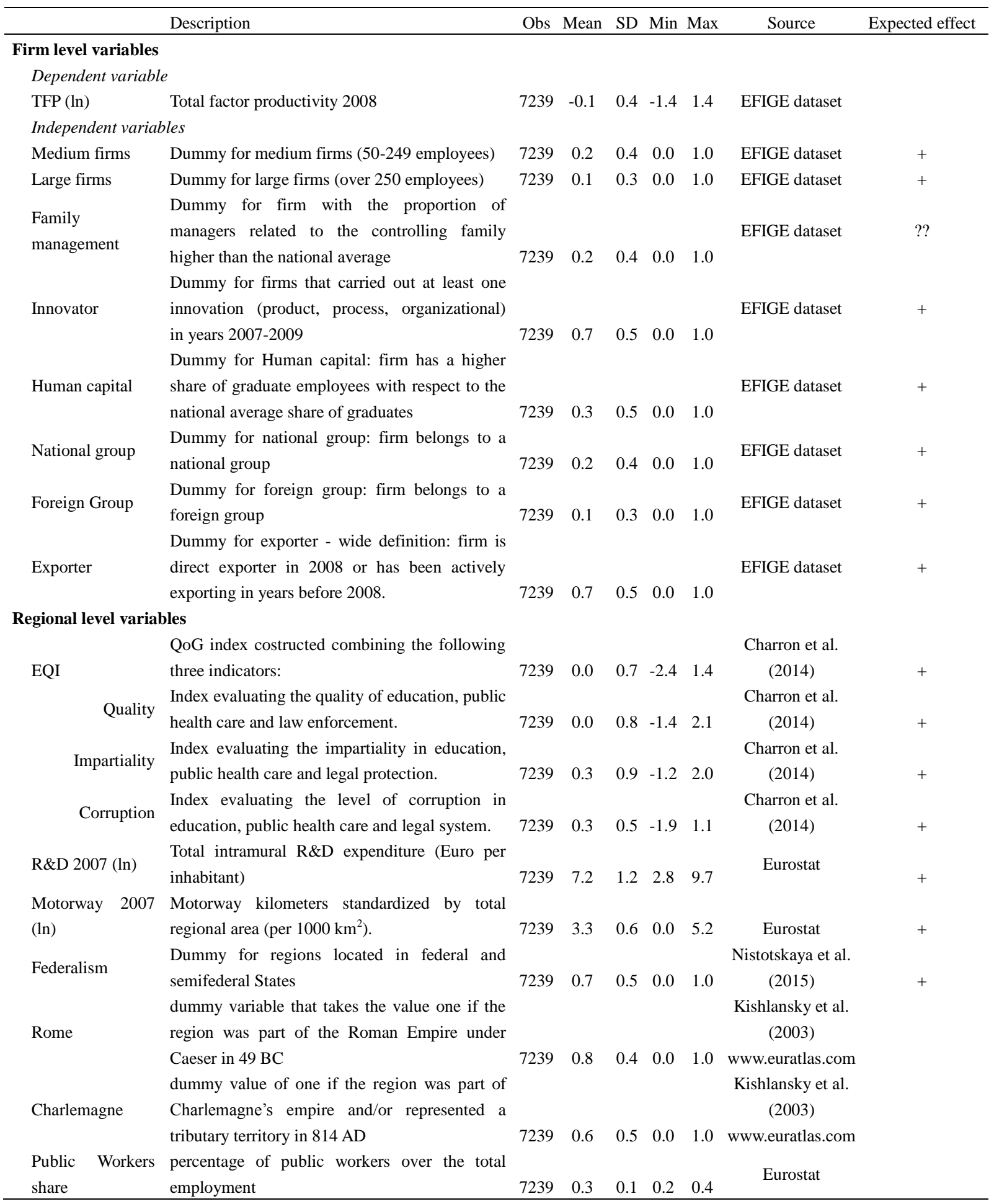

\section{Copyrights}

Copyright for this article is retained by the author(s), with first publication rights granted to the journal.

This is an open-access article distributed under the terms and conditions of the Creative Commons Attribution license (http://creativecommons.org/licenses/by/4.0/). 